\begin{tabular}{|c|c|}
\hline Title & A Compact Encoding of Plane Triangulations with Efficient Query Supports \\
\hline Author(s) & Y amanaka, Katsuhisa; Nakano, Shin-ichi \\
\hline Citation & 2010年度科学技術振興機構ERA TO湊離散構造処理系プロジェクト講究録. p.504. \\
\hline Issue Date & 2011-06 \\
\hline Doc URL & http:/hdl.handle.net/2115/48327 \\
\hline Type & conference presentation \\
\hline Note & $\begin{array}{l}\text { ERATO湊離散構造処理系プロジェクトジ業大学 大岡山キャン゙ジウム(第2回) : 第73回情報処理学会全国大会イベント企画. } \\
\text { 2011年3月. }\end{array}$ \\
\hline File Information & 03.yamanaka.pdf \\
\hline
\end{tabular}

Instructions for use 


\section{A Compact Encoding of Plane Triangulations with Efficient Query Supports}

O Katsuhisa Yamanaka(UEC Tokyo) and Shin-ichi Nakano(Gunma Univ.)
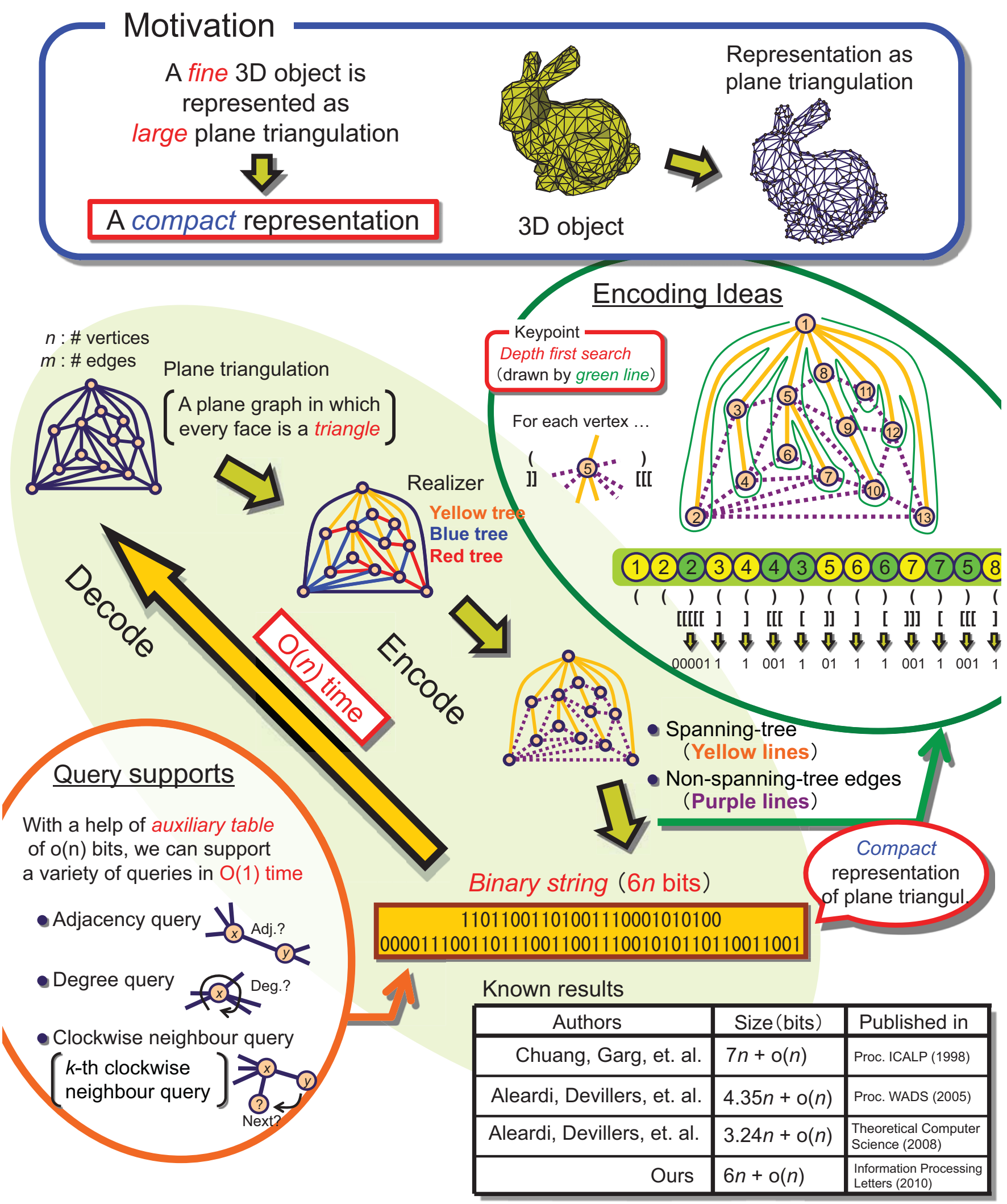